\title{
The Potentialities and Limitations for Chinese Democracy
}

\author{
Dingping Guo \\ (Fudan University, Shanghai, China)
}

\section{$\langle$ Content $\rangle$}

I. The evolution of the definitions of democracy

II. The two faces of socialist democracy
III. Two-track political developments IV. Contradictions and challenges

- Key Words: Chinese democratization, authoritarianism, constitutional democracy, $\mathrm{CCP}$, political civilization, social democracy

\section{【ABSTRACT】}

Democracy has been established as an important aim of political development and an integral element of political civilization since the late 1970s. However, it is not the liberal democracy in western societies. What China wants to promote is the socialist democracy that has two faces, that is, the socialist face and liberal face. As a result, the political developments have reflected two-track characteristics in democratization. One is to strengthen and improve the CCP leadership by introducing intra-party democracy, reinforcing party discipline, strengthening intra-party supervision and implementing mass line and people's principle based on the socialist nature of democracy. Another is to build democratic systems by upgrading the status of the NPC, expanding the scope of direct elections, reforming election rules, restoring the grass-root autonomy in countryside and urban community and improving the conditions of human rights in the view of liberal democracy. From these processes of democratization, we can evaluate the potentialities and limitations for Chinese democracy.

* This is the revised version of the paper originally prepared for the international conference "Democracy in Asia, Europe and the World: Toward a Universal Definition"to be held on 3-4 June 2004 in Seoul, Korea. I would like to express my deep gratitude to Professor Chung-Si Ahn of Seoul National University, Professor Takashi Inoguchi of Tokyo University and Professor Jae-Ho Chung of Seoul National University and other participants for their insightful comments and questions. 
As the economic and political reforms have been intensifying in China, the question whether China will democratize has been attracted attentions from abroad as well as at home. Based on different-if not contradictory-definitions of democracy, scholars and observers tend to depict their own pictures for the democratic developments in China. This paper is designed to analyze the evolution of definitions of democracy in China, clarify the complex nature of democracy in political discourse in order to look for some clues to evaluate the potentialities and limitations for Chinese democracy.

\section{The Evolution of the Definitions of Democracy}

Although the ideas of democracy were introduced into China one hundred years ago, it seems that mainland China have made little progress toward democratization owing to all kinds of reasons such as wars and revolutions. Even after reform and open-door policies began in the late 1970s, in spite of increasing demands for democratization and repeated democratic movements, the political transition from totalitarianism and/or authoritarianism to democracy has not substantially taken place up to now. The Chinese Communist Party $(\mathrm{CCP})$ is established as the sole ruling party and any opposition parties or political dissidents are harshly cracked down.

This situation resulted to some extent from improper or wrong understanding of democracy in modern history of China. Because of historical imperative for national independence and unity, democracy was adopted for some pragmatic considerations for a long time. For example, during the period of revolution and struggle against foreign invasion and imperialist intervention, democracy had been exploited as a means of political and social mobilization. Many revolutionary leaders and intellectuals sought the ideal of democracy for their patriotic spirit. As a historian pointed out, "the special road to democracy through patriotism has made modern democratic ideas have a tinge of apparent pragmatism, and exerted negative influence on the complete understanding and systematic absorbing of western democratic ideas"(Xiong, 2002: 574-575). The 1911 Revolution in which the imperial system was overthrown and replaced with a "republic"was not motivated by a desire to establish individual freedom and constitutional democracy. The guiding principles of the 1911 Revolution, as articulated by Sun Yat-sen in the "Three People's Principles", were democracy, nationalism and the "people's livelihood."Although Sun Yat-sen conceptualized democratic government as government responsive to the will of the people, he did not envision it as giving people the right to weaken effective 
centralized authority. Just like their common revolutionary forerunner, neither the Nationalist Party nor the CCP chose to interpret democracy as meaning individual freedom and human rights in the early twentieth century.

The Communist definitions of democracy have been fluid since the CCP was founded in 1921. Generally speaking, three different definitions can be ascertained in the Communist political discourses.

\section{Democracy as a revolutionary slogan.}

During the long history of communist revolution against foreign invasion and domestic dictatorship, the CCP launched a lot of student movement and worker strike for democracy in terms of general, equal, direct and secret voting. In 1940, Mao Zedong, one of founding fathers of the CCP and People's Republic of China (PRC) published a famous treatise "On New Democracy" and suggested that people's congress be established at all levels and all government leaders elected by truly general and equal voting. However, the democratic system had not been built because of the opposition status of the CCP and the war environment. The CCP emphasized democracy only as a revolutionary slogan against foreign invasion and domestic dictatorship and for political mobilization. After PRC was founded in 1949, Liu Shaoqi, another founding father put it bluntly in 1951: "When talking about elections, some people often recall the old slogan 'general, equal, direct and secret voting'. No doubt, under the past counterrevolutionarydictatorship of Chiang Kai-shek, it is progressive and significant for us to raise this propaganda slogan against Chiang Kai-shek's despotic rule. However, under the new democratic leadership, if this slogan is put into practice immediately, it is not suitable to the present conditions of Chinese people, and consequentially it is not acceptable"(Liu, 1985: 54-55).

\section{Democracy as a means of class struggle and mass movement.}

In this sense, democracy was exploited for political mobilization in the series of class struggle and mass movement. In Mao Zedong's thinking, there were long-standing populist elements. He believed that even the vanguard Party needed to be rectified and reformed through criticism from the people it led and that the masses of China should be encouraged to become involved in even the highest affairs of state (Harding, 1997: 234). This kind of democracy based on mass movement was called "grand democracy" later. Its typical forms are "to speak out freely, air their view fully, holding great debates and write big-character posters (daming defang dazibao dabianlun)" that originated from the political movement in 1950s. Mao Zedong said in 1957: "This year, masses created a kind of 
revolutionary form, the form of mass class struggle. This is to speak out freely, air their view fully, holding great debates and write big-character posters." "This form brings socialist democracy into full play. This kind of democracy exists only in the socialist countries, and can not exist in the capitalist countries"(Mao, 1977: 467-468). In the Cultural Revolution of 1966-1976, the masses had been mobilized so broadly and deeply that the country verged on the edge of anarchy. After the Cultural Revolution, as a reaction, the "grand democracy"had been discarded and the provision in Article of the 1978 constitution guaranteeing the right to "speak out freely, air their view fully, holding great debates and write big-character posters" had been eliminated by a constitutional amendment adopted by the National People's Congress (NPC, Chinese legislature) on September 10, 1980.

\section{Democracy as an important aim of political development and an integral element of political civilization.}

A new historic era in China began in December 1978 when the Third Plenum of the Eleventh Central Committee of the CCP declared the end of the large-scale turbulent class struggle of a mass character and the shift of the emphasis of the Party's work to socialist modernization. Based on the reflections on the Stalinist system and Mao Zedong's dictatorship, democracy was established as an important aim of political development in the modernization drive. Deng Xiaoping, the mastermind of the new modernization drive, pointed in 1978: "For the present, democracy should be attached special importance because during a relatively long period the democratic centralism had not been implemented completely, centralization was emphasized too much and democracy was ignored"(Deng, 1994: 144). In a famous speech on political reforms in 1980, Deng Xiaoping advocated that one of the three important tasks for the modernization drive was "to develop higher and more practical democracy than the capitalist countries in politics"(Deng, 1994: 322). This idea was embodied in a dictum "no socialism and socialist modernization without democracy" which was forged by Deng Xiaoping. After entering new twenty-first century, the CCP adopted socialist political civilization as an ultimate goal of political development and democracy has been regarded as an integral element of political civilization.

\section{The Two Faces of Socialist Democracy}

In the wake of the Cultural Revolution, political reforms aimed at building socialist 
democracy with Chinese characteristics had been discussed widely and experimented with to some extent. Although democracy has been established as an important goal of political developments, it is not the liberal democracy. What Chinese leaders want to promote is the socialist democracy. Deng Xiaoping said in a 1979 speech: "What is the democracy that Chinese people want today? The democracy that Chinese people want today is the socialist democracy or people's democracy, but not bourgeois individualist democracy"(Deng, 1994: 175). In another talk, he put it more bluntly: "In regard to democracy, we emphasize the socialist democracy in mainland China, which is different from the concept of bourgeois democracy. Western democracy means the separation of three powers, multi-party competition and so on so forth. We don't oppose adopting those systems in western countries, but we don't adopt such systems as multi-party competition, separation of three powers and bicameral legislature in mainland China"(Deng, 1993: 220).

The Chinese leaders and government have rejected the western liberal democracy for several reasons. First, Chinese experience with the western liberal democracy since the nineteenth century as well as the behaviors of Western powers in the twentieth century, deeply influenced the Chinese perspective on liberal democracy. China's relationships with liberal democratic states were shaped by this history, which cast China as a victim of western imperialism. Secondly, the failure of democratic experiments in the early twentieth century after the last emperor was brought down and a new republic was founded taught a lesson that China's socioeconomic and cultural conditions were not suitable to Western liberal democracy. Thirdly, the Chinese belief that Western values fueled social decay added another layer of reasons for rejecting Western liberal democracy (Ogden, 2002: 62). This kind of belief seemed to be shared by many advocates of Asian values, in particular Lee Kuan Yew, the senior minister of Singapore. Fourthly, the disorganization of Soviet Communist Party and collapse of Soviet Union that the CCP leader believed was caused by the political reforms and democratization in 1980 s had an impact on Chinese understanding of influences of democratization on the Communist rule. Perhaps, the most important reason is that the introduction of liberal democracy will threat the Communist monopoly of political power and make it possible for the CCP to follow the footsteps of the Soviet Communist party, the long-time brother party in socialist family.

Facing the great pressures from increasing demand for further political reforms at home and demonstration effect of third-wave democratization abroad, China adopted a balanced notion of socialist democracy which have two faces, that is, the socialist face and liberal face.

\section{The socialist nature of Chinese democracy}

The socialist face of Chinese democracy consists of at least two elements. The first 
is the Communist Party's leadership; the second is the people's principle or mass line. This notion originates from the Chinese Confucian tradition and the Communist tradition.

In traditional China, people believed that all power should emanate from above, from the center, from a single supreme ruler. Dong Zhongshu (180-115 B.C.), an eminent Confucian of the Han dynasty, suggested that the emperor was the son of heaven because he was mandated by heaven, and proposed that Confucianism be prized as the ruling orthodoxy. Emperor Wu (156-87 B.C.) of the Han dynasty, adopting Dong's proposal, began advancing Confucianism, thereby enabling it to become the dominant value system in China for about two thousand years. There had been an exaggerated ideal of the great man as leader who is an amplification of the Confucian model of the father as the ultimate authority in the family. Just as the father's word was absolute in the family, so the ruler could tolerate no challenging authorities. Confucianism believed that moral cultivation was more effective and lasting than law. "If people are guided by politics and threatened with punishment, they lose their sense of shame; if they are guided by morality and treated with rites, they become mindful of shame and personal dignity."2) Confucian theorists emphasize moral cultivation because of their belief that man is naturally good. This view of the inherent good of man is fundamental in traditional Chinese ideology. It is necessary and possible for everyone to cultivate this moral good. Ideally, the ruler has authority because he is morally superior. Ordinary people would naturally follow the example of a virtuous emperor, a patriarch who served as moral exemplar. Virtue, rather than an effective leadership performance, as a qualification for ruling was emphasized throughout the Maoist years and to lesser extent reform period, with virtue defined in terms of communist ideals. Governance hinged entirely on the moral quality of the rulers and officials over the past two thousand years. In political sense, virtue means the people's principle (Minben Zhuyi), that is, the ruler must care for people's life and regard it as his foundation of power.

The CCP has had a monopoly of political power and claimed to have moral authority because it has believed it implemented the people's principle and mass line and got the support from the Chinese people during the revolutionary period as well as reform period.

The mass line was first created in the revolutionary period based on the idea of class struggle. The idea of the disadvantaged classes overthrowing the privileged classes through interclass struggle naturally entailed the idea of mobilizing the oppressed masses to fight for their own interests against those of the oppressing classes. Thus the notion of class

2) See: The Analects of Confucius(Politics: part 2). The sentence cited here has been quoted extremely frequently by Chinese Communist publicists recently to support the "new"idea of the rule of morality (yi de zhi guo) raised by Chinese President and General Secretary of the CCP Jiang Zemin at a propaganda meeting in January 2001. 
struggle led to the Mao Zedong's stress on the importance of the masses and of mass movements and to what Mao explicitly labeled as the "mass line" in the Yan'an period (late 1930s and early 1940s) and extolled as one of precious traditions in the Communist history. The mass line means the emphasis on the interests and preferences of the common people and demands government to be responsive to them. Therefore, it is common to assert that mass line is a style of leadership, which it is, at its best, a democratic style of leadership, but which is not equivalent to liberal democracy in the West. For Western liberal democracy consists of an elaborate set of institutions and game rules to implement the principle of "consent of the governed"and to compel rulers to take into account the interests, wants, preferences and aspirations of the citizens more fully than under other forms of government (Tsou, 1986: 269-272).

During the reform years, Mao's populism and mass movement have been de-emphasized and the Communist technocracy has evolved as a new style of leadership. Nevertheless, the mass line continues to be kept as an important political principle and recently is transformed into the so-called "New Three People's Principles". This new slogan was raised by $\mathrm{Hu}$ Jintao, the General Secretary of the CCP two years ago and it read "power must be used for the sake of the people; cadres' sentiments must be tied to those of the people; and material benefits must be sought in the interest of the people." While most reformist academics and cadres agree that the new Communist leadership based on the "New Three People's Principles" is more responsive to popular demands than their predecessors, a growing number of liberal intellectuals and free-thinking cadres have cast doubt on it and thought that it remains essentially feudalistic institution because "it conjures up a saintly emperor or an incorruptible judge showing pity for and showering largess on the long-suffering people." ${ }^{3)}$ Although the "New Three People's Principles" is a new creation according to the requirement of catching up with the times and renovating, it includes no new ideas and is compatible with the old Confucian tradition of people's principle and the new Communist tradition of mass line.

There is a certain amount of similarities between the socialist characteristics of Chinese democracy and the substantive concepts of democracy expressed by Jean-Jacques Rousseau in The Social Contract. He raised two ideas that were to become building blocks in the theory of representative government. One was the idea of the "general will". The other was the notion of a lawgiver whose task was to discern and act on the general will. In China, the $\mathrm{CCP}$ has claimed that it is performing the function of representing the fundamental interests of people and expressing the general will, and asked the officials to

3) Willy Wo-Lap Lam, 'The Success of the Qinmin Strategy', http://edition.cnn.com/2004/WORLD/ asiapcf/01/26/willy.column/ 
act on the general will and meet the demands of masses by following the mass line.

\section{The liberal nature of Chinese democracy}

Another side of Chinese democracy is its liberal nature focusing on the institutional and procedural aspects of democracy and respecting democracy, freedom and human rights as the universal values. This is similar to the minimalist, Schumpeterian conception of democracy rather than the classical, Rousseau's ideas.

In Capitalism, Socialism and Democracy(1942), Schumpeter modified classical democratic theory not only by junking the idea of the general will, but also by delinking democracy's legitimacy from any pretense that politicians represent voters. Instead, Schumpeter modeled his democratic theory on the neoclassical theory of price competition: just as firms compete for business in market systems, would-be political leaders compete for votes. Although political elites must in some minimal sense be responsive to voters, democracy is not fundamentally about representation. The very core of democracy is institutionalized competition for power. Just as Adam Przeworski interpreted, "the miracle of democracy is that conflicting political forces obey the results of voting. People who have guns obey those without them. Incumbents risk their control of governmental offices by holding elections. Losers wait for their chance to win office. Conflicts are regulated, processed according to rules, and thus limited. This is not consensus, yet not mayhem either"(Przeworski, 1999: 49). Schumpeterian, procedural conception of democracy has been introduced and discussed since democracy was established as an important aim of political developments in the late 1970s.

While people's principle and mass line continue to be emphasized in the Communist political discourse, the new leadership group with Deng Xiaoping as the core began to attach special importance to the state-building and party-building by improving political structures and adopting new political rules. As early as December 1978, Deng endorsed the principle of the "institutionalization of democracy and its codification into laws," as well as the principle of the inseparability of "socialist democracy" and "socialist legality"(Deng, 1994: 146, 189). In recommendations made in August 1980, Deng repeated the extreme importance of institutionalization in democratic developments and supported proposals for revising the state constitution to enable the people to enjoy full rights of citizenship and to improve the system of people's congresses at all levels.

Along with the introduction of market mechanism and opening to the outside world (mainly Western world), there are more and more academic and cultural exchanges between China and foreign countries. Chinese government has sent thousands of scholars 
and students abroad, particularly to Japan and the United States, thereby giving them intense exposure to foreign values and ideas. As a result, Western ideas and values began to penetrate the Chinese society. Some intellectuals and college students began to be infatuated with Western democratic political systems such as multi-party system, bicameral legislature and federalism as well as political ideas such as freedom, equality and human right. For example, after the CCP government reconfirmed the ultimate goal of "four modernizations" of industry, agriculture, national defense and science \& technology, the political activists added "the fifth modernization" to protect democracy and protect people's rights and advance the four modernizations. After General Secretary of the CCP Hu Jintao raised the New Three People's Principles, some radicals indicated that what was really needed was a "fourth principle of the people", namely, that "power must be bestowed on the rulers by the people."There must be solid institutions and systems of governance that would guarantee effective popular supervision of whoever is running the country. ${ }^{4)}$

Moreover, both Chinese leaders and intellectuals began to adopt some elements of western liberal democracy and respect them as universal values when China has been involved into the process of intensifying globalization after more than two decades of reforms and developments. Democracy as a political idea and a political system appeared first in West, but it has spread all over the world and become the common assets and universal values for the mankind. When Deng Xiaoping called for the political reforms in 1980, he said: "In order to promote the democratization of the Party and state politics, economic management and the whole social life by institutionalized means, we must do researches thoroughly, compare the experiences in all countries, collect ideas and deepen insights, and put forward practical and feasible plans and measures"(Deng, 1994: 336). It is believed that some of foreign countries have established effective democratic systems that can prevent the dictatorship such as the Stalinism. During the recent years, building Chinese socialist political civilization has been regarded a new important task and democracy is an integral element of political civilization. Yu Keping, a leading political scientist in Beijing advocated that there are common fundamental political values for all mankind and democracy is the best form of government up to now. According to Yu, there are not only common elements of democracy, but also universal standards for evaluating democracy such as general elections, rule of law, check and balance of powers, participation and contestation, human rights, transparency and accountability. Yu Keping pointed out: "We should learn all advanced and reasonable things from foreign countries, including foreign political civilizations; because there are some common fundamental

4) Willy Wo-Lap Lam, 'The Success of the Qinmin Strategy', http://edition.cnn.com/2004/WORLD /asiapcf/01/26/willy.column/ 
values for all mankind such as freedom, equality and democracy, and the common institutional arrangements for protecting and developing those values such as the mechanism for checking and supervising power, the mechanism for protecting human rights in every political civilization and political theorem"(Yu, 2003: 56-62).

In the institutional devices of liberal democracy, election is playing a crucial role in the process of participation and contestation. In China, elections have attracted close attention from the CCP leaders as well as intellectuals. During the last two decades, the electoral laws have been amended a few times, electoral systems improved, the scope of direct elections expanded. Although the direct elections are undertaken only at grass-root community, the principle of general, direct and secret voting has been confirmed again by the CCP government. Deng Xiaoping said in 1987: "The conditions are not ripe for direct election at higher level. The first reason is the low level of education and culture." However, "half a century later, mainland China can conduct general direct elections in next century"(Deng, 1993: 220). Although China's most powerful legislature committee (NPC) ruled out Hong Kong holding direct elections for its chief executive in 2007 and for all lawmakers in 2008, the direct elections have been confirmed as an ultimate goal which should be realized gradually.

\section{Two-track Political Developments}

Although the CCP remains the sole ruling party and maintains the monopoly of political power, any dissidents and oppositions have been cracked down, and in this sense there are no fundamental changes in the Communist party-state system in China in spite of twenty years of high growth in economy, an irrefutable fact is that today's Chinese politics has not been as the same as twenty-five years ago, today's CCP has not been the same one as in the Cultural Revolution. With the economic developments and opening up to the outside world, some political reforms have been implemented and many changes have taken place in Chinese politics.

From the very beginning of reform era, democracy has been established as an important aim of political developments. Although the democratization in China has suffered several setbacks and not achieved breakthrough as yet, there are some progress toward socialist democracy and a number of democratic elements can be found in the political developments. Therefore, China can be described as a democratizing country just as it is a developing country. As analyzed above, there are two faces in the definitions of Chinese democracy. Because of the duality of Chinese socialist democracy, the political 
developments have reflected two-track characteristics in democratization. One is to strengthen and improve the CCP leadership by introducing intra-party democracy, reinforcing party discipline, strengthening intra-party supervision and implementing mass line and people's principle based on the socialist nature of democracy, which sometimes degenerated into a kind of soft authoritarianism. Another is to build democratic systems by upgrading the status of the NPC, expanding the scope of direct elections, reforming election rules, restoring the grass-root autonomy in countryside and urban community and improving the conditions of human rights in the view of liberal democracy.

Two years after Mao Zedong's death, the second leadership group with Deng Xiaoping as the core sought drastically to reform China's economic and political systems, because Chinese were ashamed and chagrined by the fact that socialism had produced only meager results in the preceding thirty years in comparison with the other nations of East Asia. Deng Xiaoping, who took over as China's preeminent leader in 1978, publicly declared his commitment to accelerating the long-delayed process of political institutionalization in China. In a landmark speech entitled "On the Reform of the System of Party and State Leadership" (Deng, 1994: 320-343), Deng called for political reforms which aimed at the democratization of political and social lives and the establishment of a system governed by rules, clear lines of authority, and collective decision-making institutions to replace the over-concentration of power and patriarchal rule that had characterized China under Mao. At the same time, Deng was also one of the strongest advocates of the removal of "Democracy Wall", the suppression of "bourgeois liberalizations", and the elimination of "illegal" journals and "illegal" organizations through the use of socialist laws and socialist legal systems. For him, socialist democracy is definitely not a democracy that discards the socialist legal system, the Party's leadership, and discipline and order.

China's leaders have repeated political reform of some kind since the early 1980s. Political reform became the main task of the 13th Party Congress of the CCP when Party Secretary General Zhao Ziyang called for the establishment of a new civil service system, separating the functions of the party and government, further perfecting the People's Congress system, and strengthening the rule of law. Although there were setbacks after the Tian'anmen incident in 1989, Jiang Zemin again placed political reform on the Party's agenda during the 15th Party Congress. His proposals included: further development of democracy within the system of the People's Congress and in cooperation with the democratic parties; improving the legal system and building the socialist state ruled by law; respecting and protecting human rights; restructuring government to separate it from economic enterprises; streamlining government agencies and improving the civil service system; and improving the system of democratic supervision. 
However, as social-economic problems such as inflation, disorder, corruption and instability appeared and worsened from the late 1980s, democratization and decentralization were put aside as the targets of political reform. Instead, order, centralization, efficiency and stability became the supreme targets Chinese leader pursued for economic and political development.

In fact, from the late $1980 \mathrm{~s}$, in order to solve the increasing economic and social problems, and especially to keep political order and stability, ideas directly contrary to democracy began to attract attentions. These bore the label of the "neo-authoritarianism", meaning that China should have a strong and dictatorial but technocratic government able to solve its problems, on the order of the regimes of Park Chung-Hee in Korea, Lee Kuan Yew in Singapore during the 1960s and 1970s.

After Deng Xiaoping's inspection tour to southern China in early 1992, as the market reforms were accelerated, the loss of central authority brought about by the decentralizing reforms of 1980 s became obvious and its consequence serious. As a continuation of the ideas on neo-authoritarianism, so-called neo-conservatism that called for political stability, central authority, tight social control, role of ideology and nationalism, prevailed in the mid-1990s(Chen, 1997: 593).

To a large extent, neo-conservative thought reflected a deep suspicion about liberal democracy as a way of governing China. This suspicion, first raised by neo-authoritarian thinkers, was apparently reinforced and even "justified"by two important developments in 1990s. First, the domestic chaos and instability brought about by the dissolution of the Soviet Union and regime changes in Eastern Europe forced Chinese intellectuals, including those who used to be pro-democratic, to question the validity of democracy. They began to ask if China could stand, or indeed needed the kind of democratic change occurring in the former Soviet bloc that involved state dissolution, ethnic strife, civil disorder and mass unemployment. Second, China's mounting domestic problems, resulting from accelerated market reform since 1992, also caused deep concerns among intellectuals. China's weakness was alarming: extraordinarily rapid economic growth was taking place very unevenly in a society with only limited rule and under a central government whose authority was crumbling. Corruption, crime, floating population, unemployment and income disparity all had a destabilizing effect on the social order. Grave domestic concerns and uncertainties not only strengthened the position of those who consistently supported neo-authoritarian politics, but also converted many who previously favored liberal democratic ideas to the neo-conservative camp.

Despite its differences from the official line, as Feng Chen put it, "neo-conservatism can be seen as a tacit consensus between the leadership and intellectual circles on how 
the reform should be carried out"(Chen, 1997: 612). Most of China's economic and political reforms have been put into practice according to the visions offered by neo-conservative scholars during the middle and late 1990s. The political reforms introduced since the early 1990s have been cautious to a fault.

Nevertheless, the democratic progress has been achieved in some areas and fields. As observed by Minxin Pei (1997:214-215), endogenous and incremental changes in the political institutions of the authoritarian regime are gradually forming subtle but important checks and balances against the ruling party's monopoly of power, strengthening the rule of law, and cultivating self-government at the grass-root level. Such endogenous and usually incremental institutional changes may unexpectedly pave the way for genuine democracy. The most important achievements in the democratization of China can be found in the consolidation of the NPCs, the expansion of direct elections at grass-root level, and the introduction of intra-party democracy.

During the last two decades, the status of the NPC has been consolidated and upgraded to a certain extent and its authority enhanced. The NPC could not set its agenda, which was established by the party leadership, but it did modify, revise, and on certain issues, withhold approval of party programs. The local People's Congress has made more progress toward democratization than the national one. The central leadership has allowed more political contestation at sub-national People's Congress than at the national level because local legislative contestation is less threatening to the state capacity than political opposition at the national level, and also serves the goal of controlling bureaucratism and promoting local incentive (Xia, 2000: 214). If this process continues and political contestation at the local level extends to more regions and creeps up to national level someday, the regional democracy will trigger the democratic transition at the national level.

The expansion of direct elections at grass-root level also shows that China has made steady progress toward democracy. Beginning in the late 1980s, villagers in a number of areas were given the right to choose their own village leaders and village assemblies in multi-candidate elections. Although the candidates are betted by officials from the Ministry of Civil Affairs or local Communist leaders and in some cases the elections are rigged, the elections not only make it possible for villages to remove predatory, corrupt village leaders, but also make the local leaders more accountable to their constituents (Goldman \& MacFarquhar, 1999: 12-13). The direct village elections, one of the most encouraging political reforms during recent years in China, partly have helped to prevent corruption and maintain stability in the countryside. Based on the experiences in rural areas, the direct elections have been conducted at some of urban communities. They indicate that popular participation can be constructive to and supportive of the legitimacy of the government, 
and consequentially helpful to economic and political development.

In the process of democratization in China, the intra-party democracy is especially important because there is no multi-party competition in China. No sooner did the new era of reform begin than the intra-party democracy was designated as an important task of party-building. With the market-oriented reforms intensifying, some mechanisms of competition have been introduced such as competitive elections at all levels, secret ballots in the all kinds of the CCP committees.

\section{Contradictions and Challenges}

Even by the minimalist standard of democracy, China cannot be classified as a democracy because there are no multi-party competitive elections directly participated by all adult citizens. However, since the policies of reform and opening up to the outside world were adopted in the late 1970, there have been increasing demands for democratization and democracy has been established as one of important goals in political developments and one of integral elements of political civilization. Consequentially, a lot of measures have been taken to develop the socialist democracy. China began its new long march toward democracy as its modernization drive continues. In this sense, China is defined as a democratizing country in this paper.

However, Chinese democracy is socialist democracy as defined by Chinese leaders as well as scholars, which consists of two different if not contradictory sides. Based on these dual characteristics of Chinese socialist democracy, there are two-track developments in democratization. From these processes of democratization, we can evaluate the potentialities and limitations for Chinese democracy. The potentialities of Chinese democracy lie in the old and new people's principle, the democratic style of leadership in mass line, the adoption of procedural conception of western liberal democracy and the expanded scope of direct elections. The limitations arise from the uncertainties of democratic process and the contradictions between the socialist and liberal natures of Chinese democracy, that is, the consolidation of the CCP rule and the expansion of direct competitive elections.

Like most ideals, such as those espoused by Christianity and Communism, perfect democracies do not exist. They are always in a state of becoming; they are always the result of compromise. Therefore, we are inevitably looking at snapshots not of the completed forms of democracies but of the process of democratization. China is not an exception. From the beginning of reform and opening, the CCP set two contradictory 
goals, that is, four modernizations and four principles, or put simply, economic development and the CCP leadership. The CCP always tries to maintain balance between market dynamics and macro-control, authoritarian style and democratizing forces, autonomy of associations and embeddedness in the state, decentralization and centralization, and etc. The notion of Chinese socialist democracy means that it is a mixture of Chinese cultural traditions and western political civilizations, in other word, globalization and localization. If the process of democratization continues in China, the contradictions between the consolidation of the CCP rule and the expansion of direct competitive elections will become sharper and sharper and further political reforms will be inevitable. If political reforms continue to be implemented, Chinese democracy will reach a higher level.

As observed by Larry Diamond, democracy should be viewed as a developmental phenomenon; continued democratic development is a challenge for all countries; all democracies, old and established, can become more democratic (Diamond, 1999: 18). China has been become more democratic since the reform policies were adopted in the late 1970s; it will become more democratic if the economic and political reforms continue. Democracy has been regarded as universal value, but it is important for all countries to promote democratization based on their different cultural and historical backgrounds. 


\section{References}

Chen, Feng (1997) "Order and Stability in Social Transition: Neo-conservative Political Thought in Post-1989 China", The China Quarterly, 151: 593-613.

Deng, Xiaoping (1994) Deng Xiaoping Wenxuan (Selected Works of Deng Xiaoping), Vol. II, People's Press.

Deng, Xiaoping (1993) Deng Xiaoping Wenxuan (Selected Works of Deng Xiaoping), Vol. III, People's Press.

Diamond, Larry (1999) Developing Democracy: Toward Consolidation, The Johns Hopkins University Press.

Goldman, Merle \& Roderick MacFaquhar (1999) Dynamic Economy, Declining Party-State, in: Merle Goldman \& Roderick MacFaquhar ed. The Paradox of China's Post-Mao Reforms, Harvard University Press, pp. 3-29.

Harding, Harry (1997) The Chinese State in Crisis, in: Roderick MacFarqhar, ed., The Politics of China: The Eras of Mao and Deng, Second Edition Cambridge University Press.

Liu, Shaoqi (1985) Liu Shaoqi Xuanji (Selected Works of Liu Shaoqi), Vol. II, People's Press.

Mao, Zedong (1977) Mao Zedong Xuanji (Selected Works of Mao Zedong), Vol. V, People's Press.

Ogden, Suzanne (2002) Inklings of Democracy in China, Harvard University Asia Center. Pei, Minxin (1997) "Creeping Democratization" in China, in: Larry Diamond, marc F. Plattner, Yun-han Chu, and Hung-mao Tien, ed. Consolidating the Third Wave Democracies: Regional Challenges, The Johns Hopkins University Press, pp. 213-227. Przeworski, Adam (1999) 'Minimalist Conception of Democracy: a defense', in: Ian Shapiro \& Casiano Hacker-Cordon, ed., Democracy's Value, Cambridge University Press.

Tsou,Tang (1986) The Cultural Revolution and Post-Mao Reforms: A Historical Perspective, The University of Chicago Press.

Xia, Ming (2000) "Political Contestation and the Emergence of the Provincial People's Congress as Power Player in Chinese Politics: a network explanation", Journal of Contemporary China, 9(24): 185-214.

Xiong, Yuezhi (2002) Zhongguo Jindai Minzhu Sixiangshi (Modern History of Democratic Ideas in China), Shanghai Academy of Social Sciences Press.

Yu, Keping (2003) 'Zhengzhixue de Gongli (Theorems in Political Science)', Jiangsu Social Science Journal (Nanjing), 5: 56-62. 